\title{
PERCEPTION AND ADAPTATION RESPONSES TO CLIMATE CHANGE: AN ASSESSMENT OF SMALLHOLDER LIVESTOCK FARMERS IN AMATHOLE DISTRICT MUNICIPALITY, EASTERN CAPE PROVINCE
}

\author{
Popoola, O. O. ${ }^{1}$, Monde, N. ${ }^{2}$ and Yusuf, S. F. G. ${ }^{3}$ \\ Correspondence author: S. F. G. Yusuf. Email: fyusuf@ufh.ac.za
}

\begin{abstract}
Livestock is a critical asset for many rural poor, however, the current climate crisis is affecting livestock farmers. A cross-sectional household survey was conducted in order to assess the farmers' perceptions of climate change, and its impact on production and adaptation responses. Using a multistage sampling procedure, a total of 142 smallholder livestock farmers were selected from 18 villages across the study area. Descriptive and inferential statistical tools were used and the observed results showed that there has been a perceived drastic decline in rainfall in the area over the last 25 years. Some of the perceived impacts were poor vegetation and limited grazing, scarcity of water resources, decreased livestock growth rate, weight, milk production and reproduction rates. Adaptation responses were limited as the results showed that the only response measures taken amongst the many options available were changing grazing routes, increasing grazing distances, destocking, water harvesting and storage, and increased dependence on social welfare. An examination of farmers' perceptions of their adopted responses showed that none of the response measures were perceived as significantly effective. The lack of effective response to the climate change crisis is a cause for concern, as the livestock industry is endemic to the region and sustains families and entire communities.
\end{abstract}

Keywords: Drought, Effectiveness, Perception, Risks

\section{INTRODUCTION}

Climate change has been described as the "long-term change of the earth's climate including changes in temperature, precipitation, and wind patterns over a period of several decades or longer" (Leiserowitz et al, 2014:6). The International Fund for Agricultural Development (IFAD, 2014) has predicted an increased occurrence of extreme weather events with extensive destruction of agricultural lands. This will have major implications for those whose livelihoods are dependent on farming. Livestock is a critical asset for the rural poor as it fulfils diverse economic, social and threat management functions (Calvosa, Chuluunbaatar \& Fara, 2010). The eroding force of climate change is a threat to livelihoods and simultaneously affects smallholder farmers' capacities to cope or adapt with its associated crises (Action Contre La Faim (ACF), 2013). For instance, resource-poor households, whose major assets are livestock, could lapse into poverty due to livestock losses (IFAD, 2009) arising from loss of grazing land

\footnotetext{
${ }^{1}$ Department of Agricultural Economics and Extension, University of Fort Hare, Alice. Tel.: +27 (0) 638480276 ; E-Mail: sopeinoluwabunmi@gmail.com or 201514620@ufh.ac.za; Mobile: +27 (0) 638480276 or +27 (0) 62 0760926.

${ }^{2}$ Department of Agricultural Economics and Extension, University of Fort Hare, Alice. Tel.: +27 (0) 768343568 ; E-Mail: nmonde@ufh.ac.za; Mobile: +27 (0) 768343568.

${ }^{3}$ Department of Agricultural Economics and Extension, University of Fort Hare, Alice. Tel.: +27 (0) 849913664 ; E-Mail: fyusuf@ufh.ac.za or gbolahan4la@yahoo.com
} 
that could lead to reduction in milk, meat and wool production (Calvosa et al, 2010). The literature identifies some of the challenges that could arise, including heat stress, the spread of pests and diseases and loss of vegetation, all of which could compromise rural livelihoods and propel them further into impoverishment (Turpie \& Visser, 2013). Though depicted as an alarming situation particularly for the smallholder category of farmers, it is critical to recognise their individual perception of the changing climate as it could indeed influence their adaptation responses.

Perception can be defined as the process by which organisms interpret and organise sensation to produce a meaningful experience of the world (Lindsay \& Norman, 1977; Ndamani \& Watanabe, 2015; Pickens, 2005). According to Ofuoku (2011), it is anticipated that a man's reaction to protect his well-being and future is based on his perception and interpretation of climate change. Although such perception and interpretation could differ substantially from reality (Pickens, 2005), they must be put into consideration to address socio-economic challenges (Kusakari et al, 2014; Ndamani \& Watanabe, 2015). Perception is thus a critical concept that has been observed to influence farmers' coping and adaptation responses to climate change (Gbetibouo, 2009; Molua, 2014; Mustapha et al, 2013). For example, inconsistencies between farmers' perceptions and observed climate trends could lead to suboptimal or counterproductive adaptations (Kassie et al, 2013).

Appropriate coping and adaptation choices are limited, with most farming communities able to make use of only provisional coping or adaptation mechanisms to moderate the effects of climate change (Otieno \& Muchapondwa, 2016; Wiid \& Ziervogel, 2012). The limited responses are a perpetual challenge, as no farming population is immune to the impacts of climate change. It is thus critical to understand the impacts, know the response capacities, and assess the effectiveness of the response measures in dealing with the current climate crisis. A brief by IFAD (2014) described how climate debates often overlook the effects of climate change in terms of economic and financial opportunities for smallholder farmers. According to the report, there are many opportunities where farmers can capitalise on learning to adapt to the changing climate.

Despite worldwide coverage of climate change impact, there is inter- and intra-sectoral variation in vulnerability depending on location, adaptive capacity and other socio-economic and environmental factors (Belay \& Sugulle, 2011). This draws critical attention to the need for more comprehensive climate risk impact and adaptation assessments at every possible level. In view of this statement, this study is expected to answer the following key questions:

1. What are the perceptions of livestock smallholder farmers to climate change?

2. How do smallholder farmers perceive the impacts of climate change on livestock production?

3. What are the smallholder farmers' coping and adaptation responses to climate change?

4. How do the smallholder farmers perceive the effectiveness of such response measures?

\section{RESEARCH METHODOLOGY}

A sample of 142 smallholder farmers practising livestock production in 18 villages were interviewed using a cross-sectional household survey. The villages were selected from Willowvale, Elliotdale and Idutywa in Mbahashe Local Municipality. Willowvale: Ngxakaxa Sheshegu and Ngxakaxa Phesheya kwe dip (Ward 2); Gwadana Ngaphantsi and Gwadana Phezulu (Ward 3). Elliotdale: Keti Cimakala and Keti Lalini (Ward 31), Nqadu Phezulu and 
Nqadu Kumaya (Ward 11); Ematolweni and Ntlabane (Ward 25); Nxanxashe and Kwesika Gosani (Ward 30); Khasa and Fameli (Ward 13). Idutywa: Mbanyana and Ntlanyane Kulombombo (Ward 16); Ntlonyane Kulophungla and Ezithenjini (Ward 26). Simple random sampling was used to select the wards and villages, while a snowball sampling approach was used to select the farming households.

Simple descriptive statistical tools were used to describe respondents' socio-economic characteristics and represent their perceptions of temperature and rainfall changes. Mean scores were used, following Farauta et al (2011), to analyse and describe the severity of climate change-induced risks, classified on a three-point Likert scale as 'very severe' $=3$, 'severe' $=2$, and 'not severe' $=1$. A computation of individual and overall mean scores was done. Risks with a mean score equal to or greater than $(\geq) 2.0$ were considered very severe while those with a mean score less than $(<) 2.0$ were considered not severe in the study area. Mean scores were also used to analyse and describe the extent of climate change's impact on respondents' agricultural productivity, classified on a five-point Likert scale as 'to a very great extent' $=5$, 'to a great extent' $=4$, 'to some extent' $=3$, 'to a little extent' $=2$, and 'to no extent' $=1$. A computation of individual and overall mean scores was done. Impacts with a mean score equal to or greater than $(\geq) 3.0$ were considered as affecting the respondents to a very large extent, while impacts with a mean score of less than $(<) 3.0$ were considered as affecting respondents to a minimal extent. Mean scores were also used to analyse and describe results of the assessment of smallholder farmers' perceptions of the effectiveness of their adopted response measures, classified on a three-point Likert scale as 'very effective' $=3$, 'effective' $=2$, and 'not effective' $=1$. A computation of individual and overall mean scores was done. Adaptation response measures with a mean score equal to or greater than $(\geq) 2.0$ were considered effective measures, while those with a mean score less than $(<) 2.0$ were considered not effective. Cluster analysis was conducted to generate clusters based on the similarity of responses of participants to all items provided in the perceptions of participants to the impact of climate change on their production activities. This analysis was carried out using the statistical programme, STATA/SE version 15.

\section{RESULTS}

Respondents' mean age was $59.01(\mathrm{SD}=14.10)$ years, they had on average of $18.2(\mathrm{SD}=11.61)$ years' experience as livestock farmers, and the majority $(66.2 \%)$ had either primary school level or no formal education.

\subsection{Perception of temperature and rainfall changes in the last 25 years, climate change induced risks and levels of severity}

The majority of the respondents $(86.62 \%)$ perceived that there had been changes in temperatures. A total of $91.55 \%$ had perceived a decrease in rainfall intensity compared to 20 to 30 years ago. The majority $(99 \% ; \overline{\mathrm{x}}=2.73)$ viewed drought as the most challenging phenomenon, followed by fire outbreaks $(70 \% ; \overline{\mathrm{x}}=1.61)$, heat waves $(69 \% ; \overline{\mathrm{x}}=1.53)$ and wind speed $(58 \% ; \overline{\mathrm{x}}=1.25)$.

\subsection{Perceived impact of climate change on agricultural productivity}

In addition to observed climate change-induced risks, livestock farmers had observed various impacts on their livestock production. This is as follows: decreased livestock growth rate $(\overline{\mathrm{x}}=$ 
S. Afr. J. Agric. Ext.

Vol. 47 No. 2, 2019: 46 - 57

http://dx.doi.org/10.17159/2413-3221/2019/v47n2a502
Popoola, Monde,

Yusuf

(License: CC BY 4.0)

4.06), decreased livestock weight $(\overline{\mathrm{x}}=3.55)$, and decreased milk production $(\overline{\mathrm{x}}=3.36)$ (Table 1).

\subsection{Adaptation responses and perceived effectiveness of adopted response measures}

Adaptation responses were limited to changing grazing routes $(\overline{\mathrm{x}}=1.83)$, increasing grazing distances $(\overline{\mathrm{x}}=1.59)$, destocking $(\overline{\mathrm{x}}=1.56)$, water harvesting and storage $(\overline{\mathrm{x}}=1.98)$, and increased dependence on social welfare $(\overline{\mathrm{x}}=1.74)$. None of these were perceived as effective response measures to the climate change stresses in the region (Table 2).

Table 1: Perceptions of the impact of climate change on livestock production $(n=142)$

\begin{tabular}{|c|c|c|c|c|c|c|c|}
\hline $\begin{array}{l}\text { Perception of climate } \\
\text { change impact on } \\
\text { livestock production }\end{array}$ & $\begin{array}{c}\text { Livestock } \\
\text { farmers } \\
(\%)\end{array}$ & $\begin{array}{c}\text { To no } \\
\text { extent } \\
(\%)\end{array}$ & $\begin{array}{c}\text { To a } \\
\text { little } \\
\text { extent } \\
(\%)\end{array}$ & $\begin{array}{c}\text { To } \\
\text { some } \\
\text { extent } \\
(\%)\end{array}$ & $\begin{array}{c}\text { To a } \\
\text { great } \\
\text { extent } \\
(\%)\end{array}$ & $\begin{array}{c}\text { To a very } \\
\text { great } \\
\text { extent } \\
(\%)\end{array}$ & $\begin{array}{l}\text { Mean } \\
\text { score }\end{array}$ \\
\hline $\begin{array}{l}\text { Growth rate of livestock } \\
\text { has decreased }\end{array}$ & 100 & 6 & 4 & 23 & 18 & 49 & $4.06^{*}$ \\
\hline $\begin{array}{l}\text { Milk production rate has } \\
\text { decreased }\end{array}$ & 100 & 13 & 12 & 21 & 40 & 14 & $3.36^{*}$ \\
\hline $\begin{array}{l}\text { There is an increase in } \\
\text { pest occurrence }\end{array}$ & 100 & 3 & 32 & 21 & 23 & 21 & $3.31 *$ \\
\hline $\begin{array}{l}\text { There is an increase in } \\
\text { disease occurrence }\end{array}$ & 100 & 4 & 20 & 24 & 28 & 24 & $3.54 *$ \\
\hline $\begin{array}{l}\text { Reproduction rates of } \\
\text { livestock have been } \\
\text { reduced }\end{array}$ & 100 & 8 & 27 & 24 & 25 & 16 & $3.19 *$ \\
\hline $\begin{array}{l}\text { Poor vegetation for } \\
\text { livestock feeding has } \\
\text { increased }\end{array}$ & 100 & 4 & 6 & 23 & 35 & 32 & $3.10^{*}$ \\
\hline $\begin{array}{l}\text { Grazing lands for } \\
\text { livestock have become } \\
\text { limited }\end{array}$ & 100 & 8 & 5 & 14 & 25 & 48 & $4.07 *$ \\
\hline $\begin{array}{l}\text { There have been } \\
\text { decreases in livestock } \\
\text { weight }\end{array}$ & 100 & 3 & 17 & 28 & 32 & 20 & $3.55^{*}$ \\
\hline $\begin{array}{l}\text { There have been } \\
\text { increases in livestock } \\
\text { deaths }\end{array}$ & 100 & 6 & 22 & 38 & 22 & 12 & $3.16^{*}$ \\
\hline $\begin{array}{l}\text { There is a scarcity of } \\
\text { water resources }\end{array}$ & 100 & 2 & 5 & 8 & 23 & 62 & $4.50 *$ \\
\hline $\begin{array}{l}\text { Loss of farm income or } \\
\text { earnings }\end{array}$ & 100 & 14 & 15 & 26 & 27 & 18 & $3.22 *$ \\
\hline
\end{tabular}

* Significant impact if mean score is $\geq 2$

Source: Field survey, 2016 
S. Afr. J. Agric. Ext.

Vol. 47 No. 2, 2019: 46 - 57

http://dx.doi.org/10.17159/2413-3221/2019/v47n2a502
Popoola, Monde,

Yusuf

(License: CC BY 4.0)

Table 2: Adaptation responses and their perceived effectiveness $(n=142)$

\begin{tabular}{|c|c|c|c|c|c|c|}
\hline \multirow[t]{2}{*}{$\begin{array}{l}\text { Self-adopted adaptation } \\
\text { responses }\end{array}$} & \multirow[t]{2}{*}{$\begin{array}{c}\text { Livestock } \\
\text { farmers } \\
(\%) \\
\end{array}$} & \multirow[t]{2}{*}{$\begin{array}{l}\text { No } \\
(\%)\end{array}$} & \multicolumn{3}{|c|}{$\begin{array}{l}\text { Yes } \\
(\%)\end{array}$} & \multirow[t]{2}{*}{$\begin{array}{l}\text { Mean score } \\
\text { of perceived } \\
\text { effectiveness }\end{array}$} \\
\hline & & & $\begin{array}{c}\text { Not } \\
\text { effective }\end{array}$ & Effective & $\begin{array}{c}\text { Very } \\
\text { effective }\end{array}$ & \\
\hline Using improved animal breeds & 100 & 71 & 1 & 20 & 8 & 0.65 \\
\hline Dietary change for livestock & 100 & 70 & 7 & 15 & 8 & 0.60 \\
\hline $\begin{array}{l}\text { Dipping of livestock in liquid } \\
\text { treatments }\end{array}$ & 100 & 74 & 3 & 15 & 8 & 0.59 \\
\hline Using dose treatments & 100 & 73 & 2 & 15 & 10 & 0.61 \\
\hline Vaccination of livestock & 100 & 76 & 1 & 14 & 9 & 0.56 \\
\hline $\begin{array}{l}\text { Increased use of veterinary } \\
\text { services }\end{array}$ & 100 & 89 & 2 & 6 & 3 & 0.23 \\
\hline $\begin{array}{l}\text { Making arrangements for } \\
\text { supplementary feeding in } \\
\text { cases of poor vegetation for } \\
\text { grazing }\end{array}$ & 100 & 70 & 6 & 13 & 9 & 0.59 \\
\hline $\begin{array}{l}\text { Practicing mixed livestock } \\
\text { farming system (stall fed and } \\
\text { grazing) }\end{array}$ & 100 & 87 & 6 & 5 & 2 & 0.23 \\
\hline $\begin{array}{l}\text { Practicing cross breeding of } \\
\text { local breeds }\end{array}$ & 100 & 82 & 2 & 14 & 2 & 0.37 \\
\hline $\begin{array}{l}\text { Construction of shade to } \\
\text { reduce heat }\end{array}$ & 100 & 56 & 4 & 23 & 17 & 0.99 \\
\hline Water harvesting and storage & 100 & 20 & 4 & 34 & 42 & 1.98 \\
\hline Storage of grasses (silage) & 100 & 83 & 4 & 8 & 5 & 0.35 \\
\hline Changing of grazing routes & 100 & 19 & 11 & 37 & 32 & 1.83 \\
\hline Increasing grazing distances & 100 & 25 & 13 & 39 & 23 & 1.59 \\
\hline $\begin{array}{l}\text { Diversifying sources of } \\
\text { income }\end{array}$ & 100 & 79 & 8 & 8 & 4 & 0.36 \\
\hline Destocking & 100 & 23 & 21 & 32 & 23 & 1.56 \\
\hline $\begin{array}{l}\text { Switching to another agro } \\
\text { enterprise }\end{array}$ & 100 & 92 & 1 & 6 & 1 & 0.15 \\
\hline Dependent on social welfare & 100 & 25 & 8 & 35 & 32 & 1.74 \\
\hline Use of insurance & 100 & 98 & 1 & 1 & 0 & 0.02 \\
\hline Selling assets & 100 & 94 & 4 & 3 & 0 & 0.09 \\
\hline
\end{tabular}

* Significant perceived effectiveness if mean score is $\geq 2$

Source: Field survey, 2016

\subsection{Cluster analysis}

A ward's hierarchical cluster analysis was carried out. The simulation process of the cluster analysis allocated the respondents to four clusters and this allocation process identified the frequency of respondent occurrence in each cluster (Table 3). Following Köbrich, Rehman and 
Khan's (2003) interpretation of the Dendogram, an elbow test verified the ideal number of clusters for the successive clustering method to be $n=4$ (Figure 1), which was consistent with the interpretation of the Dendogram (Burns \& Burns, 2008). G1-G10 in the Dendogram represents the boundary point for each of the clusters generated using each item on the Likert scale for the perceptions of the impact of climate change on poultry production. The Dendogram was generated by the items fed into the cluster analysis model.

Table 3: Frequencies and percentages of respondents in the four clusters

\begin{tabular}{|c|c|c|}
\hline Clusters & Frequency & Percentage \\
\hline 1 & 31 & 21.83 \\
\hline 2 & 24 & 16.90 \\
\hline 3 & 65 & 45.77 \\
\hline 4 & 22 & 15.50 \\
\hline
\end{tabular}

Source: Field Survey, 2016

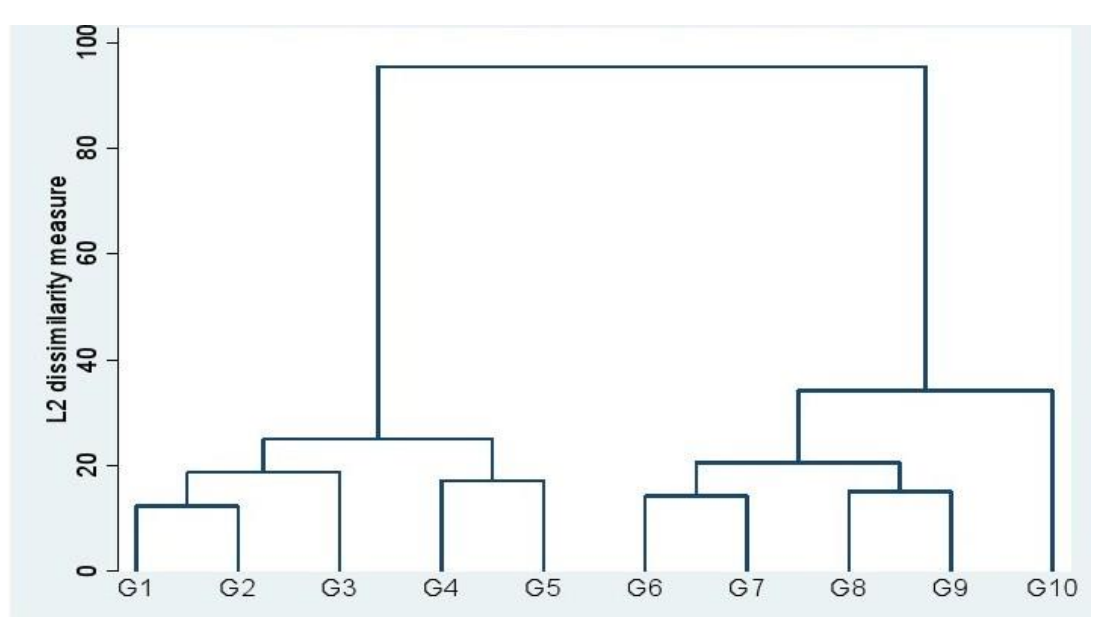

Figure 1: Dendogram for perceived impact of climate change on livestock production Source: Field Survey, 2016

Further analysis was conducted in generating mean scores for all items in the four clusters (Table 4).

Cluster 1 - Water scarcity for livestock production had the highest mean score $(\overline{\mathrm{x}}=3.81)$. This indicated the severity of lack of access to water as the most perceived impact of climate change conditions by respondents in this cluster.

Cluster 2 - Perceived increase in the scarcity of water for production activities also had the highest mean score $(\overline{\mathrm{x}}=4.29)$ indicating that it was the most severe impact for livestock farmers in this category. The perception level of the impact of scarcity of water on livestock production for this cluster was also found to be significantly higher than the perception level of respondents in the first cluster $(\overline{\mathrm{x}}=3.81)$. This could indicate that respondents in the second cluster were faced with higher constraints associated with scarcity of water than respondents in the first cluster. 
S. Afr. J. Agric. Ext.

Vol. 47 No. 2, 2019: 46 - 57

http://dx.doi.org/10.17159/2413-3221/2019/v47n2a502
Popoola, Monde,

Yusuf

(License: CC BY 4.0)

Cluster 3 - Scarcity of water for production had the highest mean score $(\bar{x}=4.68)$ in the third cluster which was found to be significantly higher than the perception of respondents to the impact of water scarcity on livestock production activities in clusters one $(\overline{\mathrm{x}}=3.81)$ and two $(\overline{\mathrm{x}}=4.29)$. This further indicates that they may be faced with greater threats of water scarcity than respondents in the first two clusters.

Cluster 4 - Water scarcity, grazing lands for livestock becoming increasingly limited, and increased disease occurrence had the highest mean scores $(\overline{\mathrm{x}}=4.95)$ in this cluster and were perceived by respondents in this group as the most severe impacts on production. All perceived items in this cluster had mean scores above 4.00 which were found to be significantly higher than the mean scores of items in the first three clusters, indicating that respondents in this group perceived all the listed impacts as more severe on their production activities than respondents in the other three clusters.

Table 4: Generated mean scores for all items in the four clusters

\begin{tabular}{|c|c|c|c|c|c|c|c|c|c|c|c|c|}
\hline Clusters & 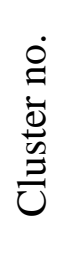 & 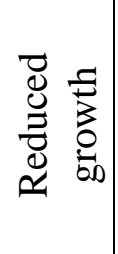 & 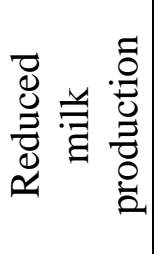 & $\begin{array}{l}\stackrel{n}{\Delta} \\
0 \\
0\end{array}$ & 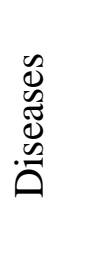 & 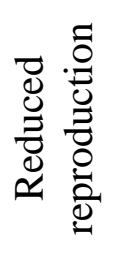 & 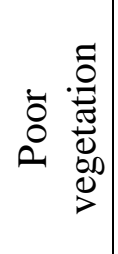 & 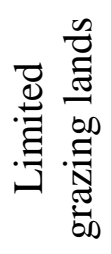 & 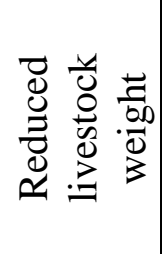 & 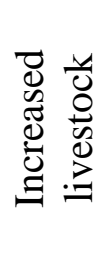 & 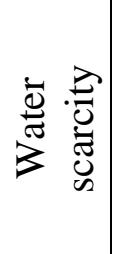 & 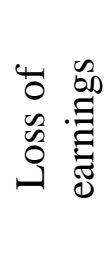 \\
\hline $\begin{array}{l}\text { Affected by } \\
\text { water } \\
\text { scarcity }\end{array}$ & 1 & 3.35 & 2.94 & 2.13 & 2.65 & 1.84 & 2.77 & 3.06 & 2.48 & 2.32 & 3.81 & 2.26 \\
\hline $\begin{array}{l}\text { Highly } \\
\text { affected by } \\
\text { water } \\
\text { scarcity }\end{array}$ & 2 & 3.25 & 2.38 & 2.63 & 2.96 & 3.54 & 3.75 & 3.46 & 3.63 & 3.33 & 4.29 & 2.88 \\
\hline $\begin{array}{l}\text { More highly } \\
\text { affected by } \\
\text { water } \\
\text { scarcity }\end{array}$ & 3 & 4.49 & 3.55 & 3.66 & 3.75 & 3.32 & 4.31 & 4.52 & 3.72 & 3.18 & 4.68 & 3.48 \\
\hline $\begin{array}{l}\text { Most highly } \\
\text { affected by } \\
\text { water } \\
\text { scarcity }\end{array}$ & 4 & 4.80 & 4.55 & 4.85 & 4.95 & 4.35 & 4.60 & 4.95 & 4.55 & 4.15 & 4.95 & 4.35 \\
\hline
\end{tabular}

Source: Field survey, 2016

\section{DISCUSSION}

The profound impacts of climate change perceived by smallholder livestock farmers in the study area were decreased livestock growth rate, decreased livestock weight, decreased milk production, decreased reproduction rates, increased pest and disease occurrences, increased poor vegetation and limited grazing land (veld), scarcity of water resources, increased livestock deaths, and loss of farm income earnings (Table 1). Similar findings were reported in Southern Malawi by Nkomwa et al (2014) in their study on indigenous knowledge systems and climate change adaptation strategies in agriculture. The current findings were also similar to those of 
Mpandeli, Nesamvuni and Maponya (2015) in their study on adapting to the impacts of drought by smallholder farmers in Sekhukhune District in the Limpopo Province, South Africa.

Sejian et al (2016) emphasised climate change-triggered heat stress in livestock as the precursor to reduced quality and quantity of meat and milk production. Specific effects observed include reduction in the daily average weight gain, body mass and conditions of the livestock, with reduced fat and lactose, and increased acidic contents in milk produced. Reproduction inefficiencies, however, result from heat stress affecting spermatocytes production in males and ovarian function and embryonic development in female livestock (Naqvi et al, 2012; Sejian et al, 2016). Shongwe (2013) observed that incursion of alien species is highly conceivable with climate change which promulgates the occurrence and intensity of livestock pests and diseases. There are strong reasons to believe that certain pests/ macro-parasites and vectorborne diseases will be capable of invading new regions which will increasingly become extremely challenging for efficient and profitable livestock production (Calvosa et al, 2010; Newton, Johnson \& Gregory, 2011).

Scarcity of water resources (drought) $(\overline{\mathrm{x}}=4.50)$ and limited grazing lands $(\overline{\mathrm{x}}=4.07)$ are clearly perceived as overwhelming problems faced by the livestock farmers in the study area. Due to the drying up of available streams, brooks and rivers, most livestock herders are compelled to travel long distances in search of water, and livestock frequently drink from dirty water, a potential source of water-borne diseases. There are reported cases of conflicts among herdsmen and communities over water usage. Furthermore, the drying and burning of grasslands has resulted in limited grazing lands and a shortage of quality grasses to feed livestock, leading to increased livestock weight loss and, in some instances, death.

Findings revealed that adaptation responses were mostly limited to changing of grazing routes, increasing grazing distances, destocking, water harvesting and storage, and dependence on social welfare (Table 1). Some of these adaptation responses were also observed by Taruvinga, Visser and Zhou (2016) in their study on determinants of rural farmers' adoption of climate change adaptation strategies in the Amathole District Municipality of the Eastern Cape Province. According to those researchers, existing livestock adaptation measures are limited and are carried out by only a small number of farmers. Moreover, Turner, McPeak and Ayantunde (2014), as well as Speranza (2010), argued that short-distance mobility, which is critical to agro-pastoral coping and adaptation mechanisms, is becoming a difficult adaptation measure due to prevailing socio-political conditions in various communities.

Destocking (mentioned by $55 \%$ as an effective response) is also an adaptation measure used in the study area. It is seen by a number of agro-pastoralists as a major type of insurance and defence mechanism (Mpandeli et al, 2015). Mpandeli et al (2015) noted that destocking is a means used by some smallholder farmers during periods of uncertainty. This suggests that farmers may not necessarily want to sell their livestock, but are forced to do so as a means of coping with climatic shocks such as drought. Speranza (2010) also indicated that destocking during harsh climatic conditions is primarily a precautionary strategy for the majority of livestock keepers and that the market prices during these times are usually lower, ultimately decreasing rather than increasing households' asset base. The fact that farmers feel compelled to sell their livestock during times of drought indicates that farmers in these communities are bearing the brunt of climate change impacts. 
The majority of the respondents also perceived that the effectiveness of their adopted responses were insignificant. Climate change adaptation may well be beyond what an individual farmer can adequately respond to, and institutional support in this case becomes crucial. An example of such institutional support may be seen in the case of Uganda, where continuous drought was addressed through an all-inclusive stakeholders' forum that led to the construction of valley dams and the provision of tanks (water reservoirs) by the government (Lim et al, 2005). Likewise, the intervention of the Ethiopian government led to the development of a comprehensive Famine Early Warning System (FEWS) to improve the coping and adaptation capacities of the rural farming population. Zougmore et al (2016) stated that the capacity of a community to adapt to climate change and its associated risks is dependent on available economic assets, geographical location, information, technologies, infrastructures, institutions and networks.

Rural communities can only achieve very little in effectively adapting to climatic shocks which again emphasises the need to pool potential external support systems that can aid in sustaining livestock production in the region. One such critical support system is the agricultural extension institution. A very significant responsibility of the extension system is to provide awareness of and capacity building trainings on contemporary technologies developed through research efforts to boost climate change resilience and adaptive capacities (Khatam, Muhammad \& Ashraf, 2013). Furthermore, the Global Alliance for Climate-Smart Agriculture (GACSA) states that extension providers can contribute to mitigation efforts by strengthening farmer groups and rural organisations. Rural advisers can also facilitate engagements with new types of institutions related to climate change, such as insurance companies, humanitarian agencies and meteorological services (GACSA, 2016).

\section{CONCLUSION AND RECOMMENDATIONS}

Findings from this study revealed that smallholder livestock farmers in the study area perceived decreased livestock growth rates, decreased livestock weight, low milk production, poor reproduction rates, increased pest and disease occurrences, poor vegetation, livestock deaths, and loss of farm income earnings as major impacts of climate change on their production activities. The area is faced with drought which has led to intense water scarcity and the drying of available grazing lands. Identified adaptation responses are mainly limited to changing grazing routes, increasing grazing distances, destocking, water harvesting and storage, and dependence on social welfare; all of which are perceived by the livestock farmers as insufficiently effective to deal with the current climatic stresses.

There is a need to buffer the individual adaptation capacities of smallholder livestock farmers in rural communities through the implementation of adaptation schemes for rural livestock sustainability. Government climate change response policy and systems need to be invigorated at the local level and to target resource-poor smallholder livestock farmers. Institutional support is needed to mitigate climate change as climate effects are beyond the capacity of smallholder farmers working alone. In addition, farmers should also be motivated to join available production, marketing and other service-oriented cooperative groups geared towards combating climate change challenges in rural communities. 


\section{REFERENCES}

ACTION CONTRE LA FAIM INTERNATIONAL (ACF), 2013. Who cares about the impact of climate change on hunger and malnutrition? A plea to the international community to ensure food and nutrition security for the most vulnerable in a changing climate. Available from: http://www.cmamforum.org/Pool/Resources/Who-cares-about-impacton-climate-change-on-hunger-and-malnutrition-ACF-2014.pdf

BELAY, L. \& SUGULLE, A.J., 2011. The impact of climate change and adoption of strategic coping mechanism by agro-pastoralists in Gabiley region, Somaliland. Available from: https://ke.boell.org/sites/default/files/the_impact_of_climate_change_in_gabiley.pdf

BURNS, R. \& BURNS, R.P., 2008. Business research methods and statistics using SPSS. London: Sage Publications Limited.

CALVOSA, C., CHULUUNBAATAR, D. \& FARA, K., 2010. Livestock and climate change: Livestock thematic papers tools for project design. Available from: https://www.ifad.org/documents/10180/48b0cd7b-f70d-4f55-b0c0-5a19fa3e5f38

FARAUTA, B.K., EGBULE, C.L., IDRISA, Y.L. \& AGU, V.C., 2011. Farmers' perceptions of climate change and adaptation strategies in northern Nigeria: An empirical assessment. Available from: file:///C:/Users/user/AppData/Local/Packages/Microsoft.MicrosoftEdge_8wekyb3d8bb we/TempState/Downloads/rps15\%20(1).pdf

GBETIBOUO, G.A., 2009. Understanding farmers' perceptions and adaptations to climate change and variability: The case of the Limpopo Basin, South Africa. IFPRI Discussion Paper No. 00849:1-36. Pretoria, South Africa.

GLOBAL ALLIANCE FOR CLIMATE-SMART AGRICULTURE (GACSA), 2016. Supporting agricultural extension towards climate-smart agriculture: An overview of existing tools. Available from: http://www.fao.org/3/a-bl361e.pdf

INTERNATIONAL FUND FOR AGRICULTURAL DEVELOPMENT (IFAD), 2009. Livestock and climate change. Livestock thematic papers tools for project design. Available from: https://www.ifad.org/documents/10180/48b0cd7b-f70d-4f55-b0c0$\underline{5 \mathrm{a} 19 \mathrm{fa} 3 \mathrm{e} 5 \mathrm{f} 38}$

INTERNATIONAL FUND FOR AGRICULTURAL DEVELOPMENT (IFAD), 2014. The adaptation advantage: The economic benefits of preparing small-scale farmers for climate change. Available from: https://www.ifad.org/documents/10180/0a24e2483f96-49af-b2df-ebbce284335c

KASSIE, B.T., HENGSDIJK, H., RÖTTER, R., KAHILUOTO, H., ASSENG, S. \& VAN ITTERSUM, M., 2013. Adapting to climate variability and change: Experiences from cereal-based farming in the Central Rift and Kobo Valleys, Ethiopia. J. Environ. Manage., 52(5):1115-1131.

KHATAM, A., MUHAMMAD, S. \& ASHRAF, I., 2013. Role of individual contact methods in dissemination of agricultural technologies. Pak. J. Agric. Res., 26(1):40-45.

KÖBRICH, C., REHMAN, T. \& KHAN, M., 2003. Typification of farming systems for constructing representative farm models: Two illustrations of the application of multivariate analyses in Chile and Pakistan. Agric. Sys., 76(1):141-157. 
KUSAKARI, Y., ASUBONTENG, K.O., JASAW, G.S., DAYOUR, F., DZIVENU, T., LOLIG, V., DONKOH, S.A., OBENG, F.K., GANDAA, B. \& KRANJACBERISAVLJEVIC, G., 2014. Farmer-perceived effects of climate change on livelihoods in Wa West District, Upper West Region of Ghana. J. Disaster Res., 9(4):516-528.

LEISEROWITZ, A., FEINBERG, G., ROSENTHAL, S., SMITH, N., ANDERSON, A., ROSER-RENOUF, C. \& MAIBACH, E., 2014. What's in a name? Global warming vs. climate change. Available from: http://climatecommunication.yale.edu/wpcontent/uploads/2014/05/Global-Warming_Climate-Change_Report_May_2014.pdf

LIM, B., SPANGER-SIEGFRIED, E., BURTON, I., MALONE, E. \& HUQ, S., 2005. Adaptation policy frameworks for climate change: Developing strategies, policies and measures. Cambridge: Cambridge University Press.

LINDSAY, P.H. \& NORMAN, D.A., 1977. Human information processing: An introduction to psychology. 2nd ed. New York: Academic Press.

MOLUA, E.L., 2014. Climate change perception and farmers' adoption of sustainable land management for robust adaptation in Cameroon. J. Agric. Sci., 6(12):202-214.

MPANDELI, S., NESAMVUNI, E. \& MAPONYA, P., 2015. Adapting to the impacts of drought by smallholder farmers in Sekhukhune District in Limpopo Province, South Africa. J. Agric. Sci., 7(2):115-124.

MUSTAPHA, B., SALAU, E.S., GALADIMA, O.E. \& ALI, I., 2013. Knowledge, perception and adaptation strategies to climate change among farmers of Central State Nigeria. Sustain. Agric. Res., 2(3):107-117.

NAQVI, S.M.K., KUMAR, D., PAUL, R.K. \& SEJIAN, V., 2012. Environmental stresses and livestock reproduction. In Environmental stress and amelioration in livestock production (pp.97-128). Berlin: Springer.

NDAMANI, F. \& WATANABE, T., 2015. Farmers' perceptions about adaptation practices to climate change and barriers to adaptation: A micro-level study in Ghana. Water, 7(9):4593-4604.

NEWTON, A.C., JOHNSON, S.N. \& GREGORY, P.J., 2011. Implications of climate change for diseases, crop yields and food security. Euphytica, 179(1):3-18.

NKOMWA, E.C., JOSHUA, M.K., NGONGONDO, C., MONJEREZI, M. \& CHIPUNGU, F., 2014. Assessing indigenous knowledge systems and climate change adaptation strategies in agriculture: A case study of Chagaka village, Chikhwawa, Southern Malawi. Phys. Chem. Earth, 67:164-172.

OFUOKU, A.U., 2011. Rural farmers' perception of climate change in central agricultural zone of Delta State, Nigeria. Indones. J. Agric. Sci., 12(2):63-69.

OTIENO, J. \& MUCHAPONDWA, E., 2016. Agriculture and adaptation to climate change: The role of wildlife ranching in South Africa. Working Paper 579. ERSA, South Africa.

PICKENS, J., 2005. Attitudes and perceptions. In Organizational behavior in health care (pp.43-67). Sudbury: Jones and Bartlett Publishers.

SEJIAN, V., GAUGHAN, J.B., BHATTA, R. \& NAQVI, S.M.K., 2016. Impact of climate change on livestock productivity. Available from: https://www.researchgate.net/publication/296282601_Impact_of_climate_change_on_li vestock_productivity 
SHONGWE, P., 2013. Cost benefit analysis of climate change adaptation strategies on crop production systems: A case of Mpolonjeni Area Development Programme (ADP) in Swaziland. MSc Thesis, University of Swaziland.

SPERANZA, C.I., 2010. Drought coping and adaptation strategies: Understanding adaptations to climate change in agro-pastoral livestock production in Makueni District, Kenya. Eur. J. Dev. Res., 22(5):623-642.

TARUVINGA, A., VISSER, M. \& ZHOU, L., 2016. Determinants of rural farmers' adoption of climate change adaptation strategies: Evidence from the Amathole District Municipality, Eastern Cape Province, South Africa. IJSED., 7(9):687-692.

TURNER, M.D., MCPEAK, J.G. \& AYANTUNDE, A., 2014. The role of livestock mobility in the livelihood strategies of rural peoples in semi-arid West Africa. Hum. Ecol., 42(2):231-247.

TURPIE, J. \& VISSER, M., 2013. Chapter 4: The impact of climate change on South Africa's rural areas.

Available from: file:///C:/Users/user/AppData/Local/Packages/Microsoft.MicrosoftEdge_8wekyb3d8bb we/TempState/Downloads/Chapter_4_Impact_of_climate_change_on_South_Africas_r ural_areas2\%20(1).pdf

WIID, N. \& ZIERVOGEL, G., 2012. Adapting to climate change in South Africa: Commercial farmers' perception of and response to changing climate. S. Afr. Geogr. J., 94(2):152173.

ZOUGMORÉ, R., PARTEY, S., OUÉDRAOGO, M., OMITOYIN, B., THOMAS, T., AYANTUNDE, A., ERICKSEN, P., SAID, M. \& JALLOH, A., 2016. Toward climatesmart agriculture in West Africa: A review of climate change impacts, adaptation strategies and policy developments for the livestock, fishery and crop production sectors. Agric. Food Sec., 5(1):1-26. 
